\title{
LASER-INDUCED FLUORESCENCE OF ORGANIC MATTER FROM A BRAZILIAN OXISOL UNDER SEWAGE-SLUDGE APPLICATIONS
}

\author{
Martha González Pérez ${ }^{1,2}$; Débora Marcondes Bastos Pereira Milori ${ }^{1}$; Ladislau Martin-Neto ${ }^{1 *}$; \\ Luiz Alberto Colnago ${ }^{1}$; Otávio Antonio de Camargo ${ }^{3}$; Ronaldo Berton ${ }^{3}$; Wagner Bettiol ${ }^{4}$ \\ ${ }^{1}$ Embrapa Instrumentação Agropecuária - C.P. 741 - 13560-970 - São Carlos, SP - Brasil. \\ ${ }^{2}$ USP/IQSC - C.P.780 - 13560-250 - São Carlos, SP - Brasil. \\ ${ }_{4}^{3}$ IAC - C.P. 28 - 13020-902 - Campinas, SP - Brasil. \\ ${ }^{4}$ Embrapa Meio Ambiente - C.P. 69 - 13820-000 - Jaguariúna, SP - Brasil. \\ *Corresponding author <martin@cnpdia.embrapa.br>
}

ABSTRACT: Sludge applications have been used to maintain fertility of agricultural soils without damaging the natural ecosystem. The aim of this study was evaluating the influence of sewage-sludge addition on the quality of organic matter (OM) of a Brazilian Oxisol by Laser Induced Fluorescence (LIF). LIF was used to analyze OM of whole soil and different soil fractions separated by chemical and physical methods. The high fluorescence contribution of humin fraction to the fluorescence of whole soils was shown, stressing the importance of studying OM associated to mineral matrix of soil. Spectra with different shapes were obtained for every particle size fraction, indicating differences in organic compounds bounded to them. The fraction with the higher carbon content was the $2-20 \mu \mathrm{m}$, that contains $\sim 5 \% \mathrm{C}$ and represents only $10 \%$ in soil, but stores $34-39 \%$ of total $\mathrm{C}$ and shows the highest fluorescence intensity. The spectrum of this fraction shows its heterogeneity and a higher concentration of compounds which fluorescence is centered at $510 \mathrm{~nm}$. This indicates a higher concentration of unsaturated bond systems capable of high degree of resonance, increased conjugation of the electron $\pi$ system, and higher aromaticity comparing with other fractions. No differences were detected for treatments of sewage-sludge applications. LIF spectroscopy is a promising technique for OM studies in whole soils, allowing to study spatial distribution of OM within the soil's mineral matrix, including Oxisols.

Key words: tropical soil, spectroscopy, particle size fraction, chemical fractions

\section{FLUORESCÊNCIA INDUZIDA POR LASER DA MATÉRIA ORGÂNICA DE UM LATOSSOLO BRASILEIRO TRATADO COM LODO DE ESGOTO}

\begin{abstract}
RESUMO: A aplicação do lodo de esgoto é utilizada como alternativa de conservação e manutenção da fertilidade dos solos sem prejudicar o ecossistema. O objetivo do presente trabalho foi avaliar a influência da aplicação de lodo de esgoto sobre a matéria orgânica (MO) de um Latossolo vermelho amarelo brasileiro, através da fluorescência induzida por laser (LIF). A LIF foi utilizada para analisar a fluorescência do solo intacto e suas frações químicas e físicas. Houve grande contribuição da fração humina à fluorescência do solo intacto, remarcando a importância de estudar a matéria orgânica (MO) associada à matriz mineral do solo. Para cada fração granulométrica foram obtidos espectros com diferentes perfis, indicando diferenças nos compostos orgânicos a elas ligados. A fração 2-20 $\mu \mathrm{m}$, que apresentou maior conteúdo de carbono ( $\sim 5 \%$ ), representa somente $10 \%$ do solo mas acumula $34-39 \%$ do conteúdo total de carbono do mesmo e mostrou a maior intensidade de fluorescência. O espectro desta fração mostra sua heterogeneidade e alta concentração de compostos cuja fluorescência é centrada nos $510 \mathrm{~nm}$, o que indica alta concentração de sistemas com ligações insaturadas, com alto grau de ressonância e maior conjugação do sistema de eletrons $\pi$, indicando maior aromaticidade quando comparado as outras frações. Não foram observadas diferenças significativas entre os tratamentos de lodo de esgoto. A LIF é uma técnica promissora para caraterizar a MO de solos intatos, permitindo estudar sua distribuição na matriz mineral do solo, inclusive nos Latossolos. Palavras-chave: solos tropicais, espectroscopia, frações granulométricas, frações químicas
\end{abstract}

\section{INTRODUCTION}

One of the agricultural priorities is to sustain and maintain fertility levels of soil without damaging the natural ecosystem. Alternatives such as sludge applications have been recommended to achieve this ob- 
jective (Melo \& Marques, 2000). Sludge is a significant source of supplementary nitrogen, phosphorus and other essential nutrients for plant growth. Once it also incorporates high quantities of organic matter (OM) that improve fertilization level and some physicalchemical properties of soils in land restoration (Melo \& Marques, 2000; Piccolo et al., 1992), their disposal on agricultural soils has been strongly promoted. In addition to these agricultural benefits, the incorporation of organic amendments and crop residues into the soil, in some situations, can reduce emissions of $\mathrm{CO}_{2}$ due to carbon fixation, with meaningful implications for mitigation of the greenhouse effect (Bayer et al., 2000).

A simple and sensitive techniques used for structural and functional characterization of humic substances is the fluorescence spectroscopy (Senesi et al., 1991; Zsolnay et al., 1999; Kalbitz et al., 2000; Milori et al., 2002). Recently, Milori et al. (2006) show that Laser Induced Fluorescence spectroscopy (LIF) can be also used in whole soil for OM structural characterization.

In this study, LIF was used to characterize structural changes in $\mathrm{OM}$ of whole Typic Hapludox (Latossolo vermelho amarelo) amended with sewagesludge, and its particle size fractions. Our aim was to analyze the influence of sewage-sludge addition on soil $\mathrm{OM}$ and to evaluate the humification degree of $\mathrm{OM}$ through fluorescence behavior of whole soils and different fractions separated by chemical and physical methods.

\section{MATERIAL AND METHODS}

Soil samples were collected from the superficial layer $(0-20 \mathrm{~cm})$ of a Typic Hapludox (Haplic Ferralsol, FAO classification) of the experimental Station in Jaguariuna, state of Sao Paulo, Brazil. The soil contained $430 \mathrm{~g} \mathrm{~kg}^{-1}$ clay, $70 \mathrm{~g} \mathrm{~kg}^{-1}$ silt and $500 \mathrm{~g} \mathrm{~kg}^{-1}$ sand. Organic matter content determined by WalkleyBlack method (Nelson \& Sommers, 1996) was $32 \mathrm{~g}$ $\mathrm{kg}^{-1}$. The experimental Station is located at the geographic coordinates $22^{\circ} 41^{\prime} \mathrm{S}, 47^{\circ} \mathrm{W}$ in $570 \mathrm{~m}$ altitude, in a subtropical region with a mean annual temperature of $22^{\circ} \mathrm{C}$, humid summers and dry winters.

The 2-year field experiment evaluated rates of sewage sludge from urban wastes, treated at the sewage-sludge treatment station at city of Franca, state of Sao Paulo, Brazil, in soil amendment. Soil treatments were: control (non-cultivated soil under natural vegetation $(N C)$ ), control soil amended with NPK (conventional corn fertilization) and four sewage-sludge applications (N1, N2, N4 and N8). Treat- ment N1 was equivalent to the dose of nitrogen applied as conventional mineral fertilization in corn (3.5 $\left.\mathrm{Mg} \mathrm{ha}^{-1}\right)$; the other doses were 2, 4 and 8 times the quantity of sewage sludge of treatment N1, respectively 7, 14 and $28 \mathrm{Mg} \mathrm{ha}^{-1}$ of sewage sludge (dry matter).

\section{Chemical fractionation}

The IHSS method was used for the extraction of humic substances from soil: extraction with 0.1 mol L ${ }^{-1} \mathrm{NaOH}$, precipitation with $6 \mathrm{~mol} \mathrm{~L}^{-1} \mathrm{HCl}$, dialyses and freeze-drying as last step (Stevenson, 1994).

\section{Particle size fractionation}

After soil samples were air-dried at room temperature, roots and visible plant remains were manually removed and samples. Were divided into four particle size fractions by a combination of wet sieving and sedimentation (Tanner \& Jackson, 1947). The sand fraction $>53 \mu \mathrm{m}$ was separated by wet sieving after 8 minutes dispersion with ultrasonic treatment. The other three fractions were separated using sedimentation cylinders into one clay fraction $(<2 \mu \mathrm{m})$ and two silt fractions $(2-20 ; 20-53 \mu \mathrm{m})$.

\section{Hydrofluoric acid treatment}

All samples of whole soils were treated with $10 \%$ HF (hydrofluoric acid) solution according to Gonçalves et al. (2003) using a 1:8, soil to acid ratio, and changing acid solution at least six times every two hours.

\section{Elemental analysis}

Elemental composition ( $\mathrm{C}, \mathrm{H}, \mathrm{N}, \mathrm{S})$ of humic acid (HA) was determined using a Fisons Instruments Elemental Analyzer EA 1110.

\section{Laser Induced Fluorescence (LIF) experiments}

LIF emission spectra were recorded using pellets of soils and powder particle size fractions, in an experimental setup developed and described by Milori et al. (2006). To excite soil fluorescence, an argonium laser equipment syntonized at $351 \mathrm{~nm}$ with exit power of $400 \mathrm{~mW}$ was used. A prism was placed in front of the laser exit to remove background gas fluorescence. The back scattering fluorescence emitted by excited samples was collected through a convergent lens and focused on the slit of a monochromator (focal distance $240 \mathrm{~mm}, 1200 \mathrm{~g} \mathrm{~mm}^{-1}$, and blaze $500 \mathrm{~nm}$ - CVI). Signals were multiplied by a Hamamatsu photomultiplier, adjusted to the maximum sensitivity in the visible region $(530 \mathrm{~nm})$, and filtered and amplified by a lock-in amplifier. System operation and data acquisition were controlled by specific software. The spectral resolution was adjusted to $4 \mathrm{~nm}$. 


\section{RESULTS AND DISCUSSION}

\section{LIF of whole soils}

Soil carbon contents determined before and after $10 \%$ HF treatment are shown in Table 1. Carbon contents of soils was circa $2 \%$ and similar for all treatments. The $10 \%$ HF treatment increased the carbon content to $5.8-11.0 \%$ in samples, as a consequence of dissolution of iron oxides and minerals.

Emission spectra of some whole soil samples are shown in the Figure 1a. The comparison among different spectra was made possible though the normalization by the carbon percentage. All spectra show broad bands ( 350 to $650 \mathrm{~nm}$ ), resulting from overlapping of at least two bands centered at 452 and $507 \mathrm{~nm}$. These bands are associated with more conjugated compounds. No significant differences were observed among different soil treatments, probably the heterogeneity of soils is interfering and averaging the fluorescence and the carbon determination, as the fraction that has the lowest carbon content constituted $50 \%$ of the soil.

Treatment of the whole soil with $10 \% \mathrm{HF}$ was aimed to reduce contents of paramagnetic materials. This is the standard procedure, in many cases, for studying whole soils or humic acids (Schmidt et al., 1997; 2000, Dai \& Johnson, 1999; Skjemstad et al., 1994; Gonçalves et al., 2003).

Comparing normalized spectra, before and after $10 \%$ HF treatment, shows that the shape of the spectrum changes as consequence of HF treatment (Figure 1b). The maximum of the spectrum before HF treatment at $452 \mathrm{~nm}$ shifts $20 \mathrm{~nm}$ towards a lower wavelength, and the intensity of the shoulder centered at $507 \mathrm{~nm}$ decreases, so that this band is almost disappearing for all treatments. Exchangeable cations, in this case specifically iron, act as a bonding link among carbonyl and carboxyl groups of organic matter and clay minerals (Varadachari et al., 1997). The HF 10\%

Table 1 - Carbon content of whole soils, and particle size fractions.

\begin{tabular}{lcccccc}
\hline \multicolumn{7}{c}{ Carbon content } \\
\hline Sample & Control & NPK & N1 & N2 & N4 & N8 \\
\hline Whole soil & 1.60 & 1.74 & 1.99 & 2.43 & 1.88 & 1.78 \\
$<2 \mathrm{~mm}$ & 2.37 & 2.25 & 2.17 & 2.33 & 2.32 & 2.59 \\
$2-20 \mathrm{~mm}$ & 5.39 & 4.24 & 5.27 & 5.37 & 5.88 & 5.99 \\
$20-53 \mathrm{~mm}$ & 0.87 & 0.98 & 1.02 & 0.84 & 0.82 & 1.40 \\
$>53 \mathrm{~mm}$ & 0.30 & 0.45 & 0.27 & 0.28 & 0.33 & 0.54 \\
\hline Whole soil* & 11.00 & 5.80 & 5.92 & 7.28 & 6.43 & 9.32 \\
\hline
\end{tabular}

*Treated with $10 \%$ hydrofluoric acid. treatment did not only dissolve iron oxides, but also caused the loss of compounds bounded to them, as a result of either the removal of labile compounds soluble in water or the diminution of the extension of conjugation of the electron $\pi$ system, as consequence of breaking the organo-mineral complex. The quality of results obtained through magnetic resonance techniques is better, but on the other hand structural information is lost. The affected compounds should be aromatic rings with a high degree of conjugation of the electron $\pi$ system and/or highly substituted by carbonyl and carboxyl groups (McGarry \& Baker, 2000; Senesi et al., 1991).

\section{LIF of chemical fractions: humin and humic acids}

Figure 2 shows the spectra of humin and humic acid fractions resulting from chemical fractionation. All spectra were compared at the same reflectance level, after equalizing the fluorescence intensity
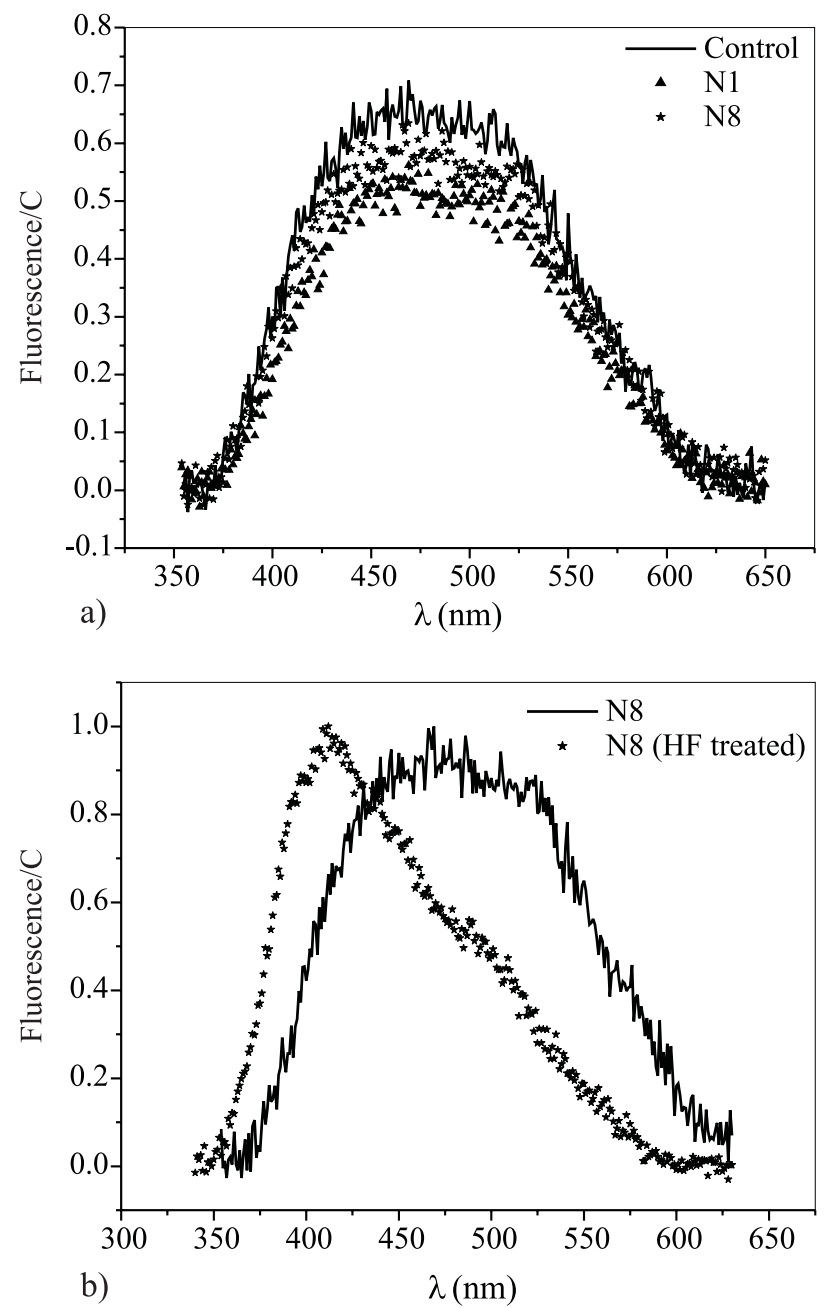

Figure 1 - a) LIF emission spectra of whole soil samples of different treatment. b) Comparison between LIF emission spectra of whole soil before and after $10 \%$ $\mathrm{HF}$ treatment given in Fluorescence/C. 

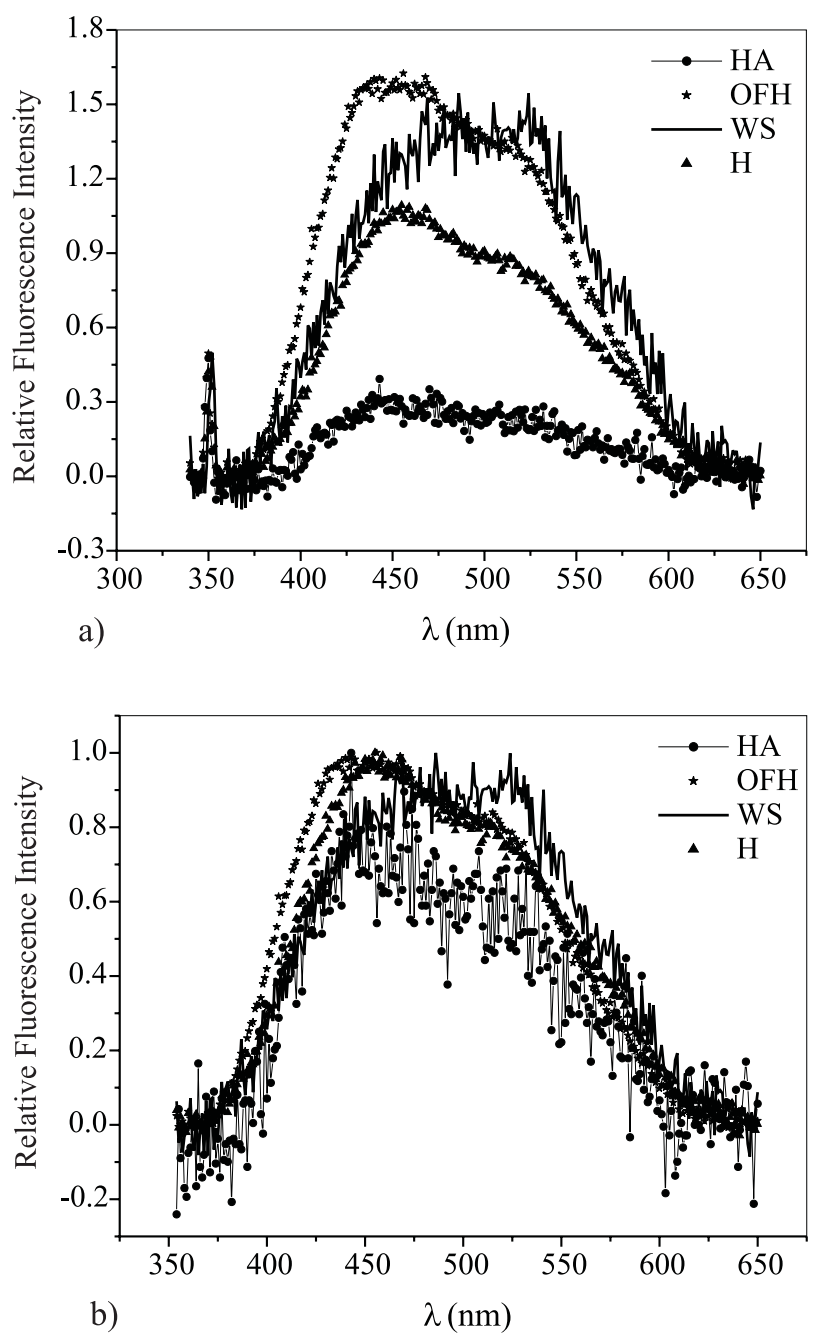

Figure 2 - a) LIF emission spectra of N8 whole soil (WS) sample and fractions obtained by chemical fractionation: humin $(\mathrm{H})$, humic acid (HA) and organic fraction of humin separated after $10 \%$ HF treatment $(\mathrm{OFH})$. b) The normalized spectra of Figure 2a.

of the $351 \mathrm{~nm}$ laser line. Humin shows much higher fluorescence intensity than the HA fraction (Figure 2). The same result was obtained for all treatments. Therefore, the contribution of humin fraction to fluorescence intensity of whole soils is meaningful.

Many researchers study soil OM through humic or fulvic acid characteristics. However, only about $70 \% \mathrm{OM}$ is insoluble. The humin fraction, especially, contains high amounts of only slightly altered lignin and polysaccharides (Zech et al., 1997). In Figure 2a the area of spectrum of the humin fraction represents $69 \%$ of the area of whole soil, while the area of the spectrum of HA represents only $18 \%$. Figure $2 \mathrm{a}$ also shows the spectrum of the organic fraction separated by $10 \% \mathrm{HF}$ treatment from humin. The latter fraction is more fluorescent than whole soil and humin. Comparing the normalized spectrum of whole soil to the spectra of other fractions (Figure 2b), it is observed that the shoulder centered at $515 \mathrm{~m}$ is less intense for the fractions extracted chemically from soil, being this decrease higher for HAs, thus indicating changes that OM suffer during the extraction of HAs. Also, the effect of HF treatment under chemically extracted humin is very small, in comparison to whole soils (Figure 1b). It is observed only an enlargement in the lower wavelengths region of the spectrum. There are no losses of labile soluble compounds, the separation of organic part from mineral soil matrix decrease of the extension of conjugation.

Humin contains high concentrations of conjugated systems (probably aromatics) and/or a high degree of carbonyl and carboxyl substitution (McGarry \& Baker, 2000; Senesi et al., 1991). Reported results agree with those of other reports. Martin-Neto et al., (2000) describe the humin fraction as the main fraction of wetlands from the State of Rio de Janeiro, Brazil. They reported that humin has high concentration of semiquinone-type free radicals, that is, it is more humified than humic or fulvic acids. Derenne et al. (2000) report that resistant organic residues are composed mostly of melanoidins and black carbon. The latter is composed of two types of polyaromatics components that can only be poorly detected by ${ }^{13} \mathrm{C} N M R$ or pyrolysis, but is detectable by high-resolution transmission electron microscopy (HRTEM).

\section{LIF of particle size fractions}

Figure $3 \mathrm{a}$ depicts the percent distribution of particle size fractions in soils, and Figure $3 \mathrm{~b}$ their percentage of the total $\mathrm{C}$ content. Carbon content of particle size fractions for each treatment is also shown in Table 1 . The highest carbon content $(\sim 5 \%)$ was found in the 2-20 $\mu \mathrm{m}$ fraction that stores $34-39 \%$ of total soil carbon, followed by the $<2 \mu \mathrm{m}$ fraction $(2.17-2.59 \%$ C) that accumulates $44-53 \%$ of total soil carbon, the $20-53 \mu \mathrm{m}$ fraction $(0.82-1.40 \% \mathrm{C})$ that retains less than $3 \%$ of total soil carbon, and the big $>53 \mu \mathrm{m}$ fraction $(<1 \% \mathrm{C})$, which constituted $\sim 50 \%$ of soil but retained $9-14 \%$ of total soil carbon. Because this kind of soil has very low carbon content, studies on soil OM are difficult.

Figure 4 shows a comparison of the spectra of different particle size fractions. All spectra were compared at the same reflectance, after equalizing the fluorescence intensity of the $351 \mathrm{~nm}$ laser line. The shape of the spectra is different for every fraction. The spectrum of $<2 \mu \mathrm{m}$ fraction shows a broad band with maximum intensity at $510 \mathrm{~nm}$ and a shoulder at $465 \mathrm{~nm}$, while in the spectrum of 2-20 $\mu \mathrm{m}$ fraction, occur the two maxima at 465 and $510 \mathrm{~nm}$, the first having higher intensity. The spectra of fractions $20-53 \mu \mathrm{m}$ and 

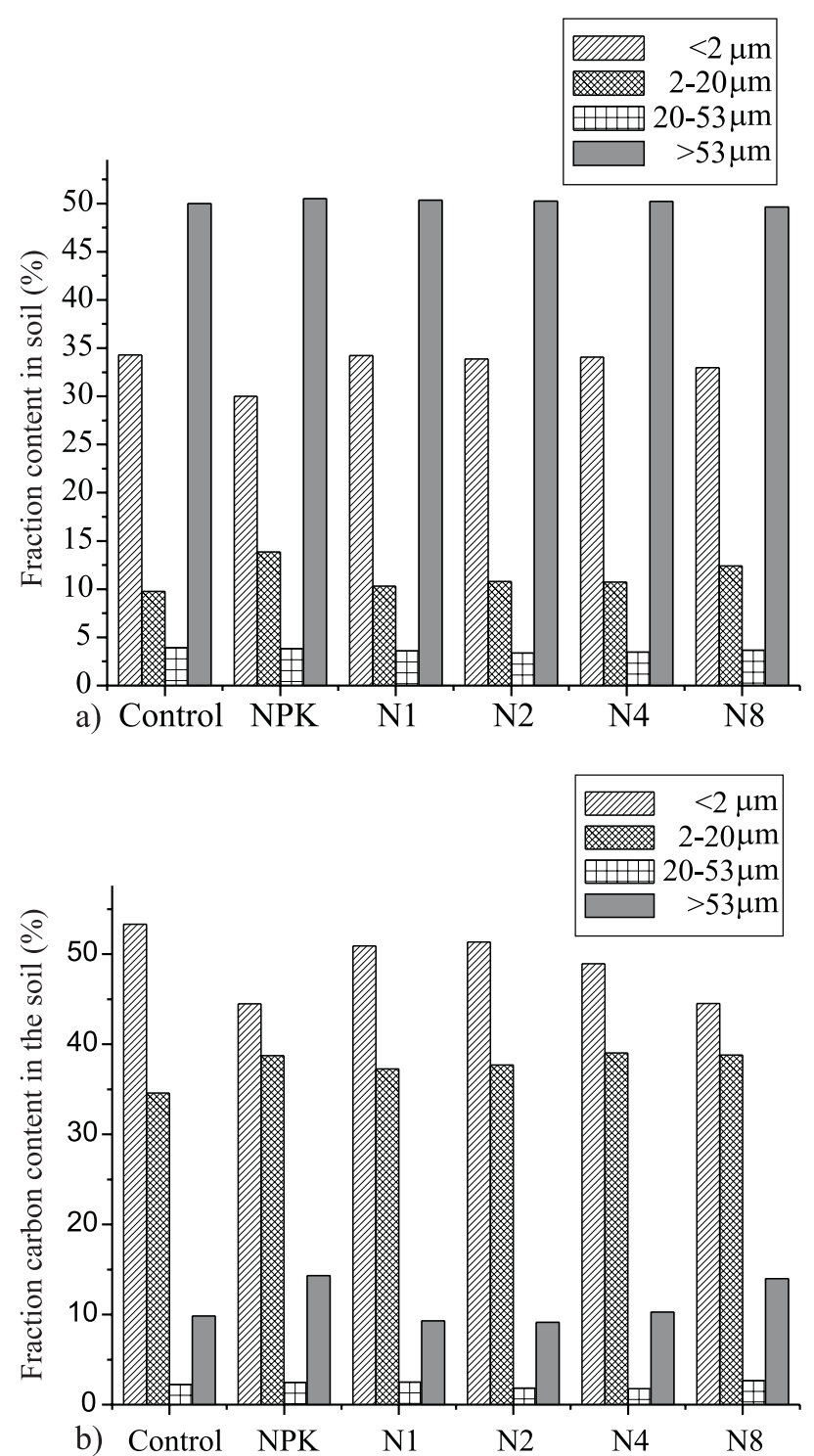

Figure 3 - a) Concentration of particle size fraction in the soil expressed in \%. b) Carbon content of particle size fractions.

$>53 \mu \mathrm{m}$ are similar, and show a broad band with two maxima at $455 \mathrm{~nm}$ and $510 \mathrm{~nm}$. This probably means that every mineral fraction bounds organic compounds with a different composition. Emission spectra of particle size fractions were similar in shape and intensity when soil treatments were compared.

Oades et al. (1987) studied organo-mineral associations by ${ }^{13} \mathrm{C}$ CPMAS NMR spectroscopy in a Redbrown Earth. They report that coarse fractions $(>53 \mu \mathrm{m})$ had presence of carbohydrates, probably cellulose, together with methoxyl groups from decomposition of lignin. The finer fractions showed an increase quantity of alkyl C. The authors concluded that, in part, this arise from polymethylene and greater proportion of aromatic carbons, with a maximum content in the silt fraction $(2-20 \mu \mathrm{m})$. They also concluded that

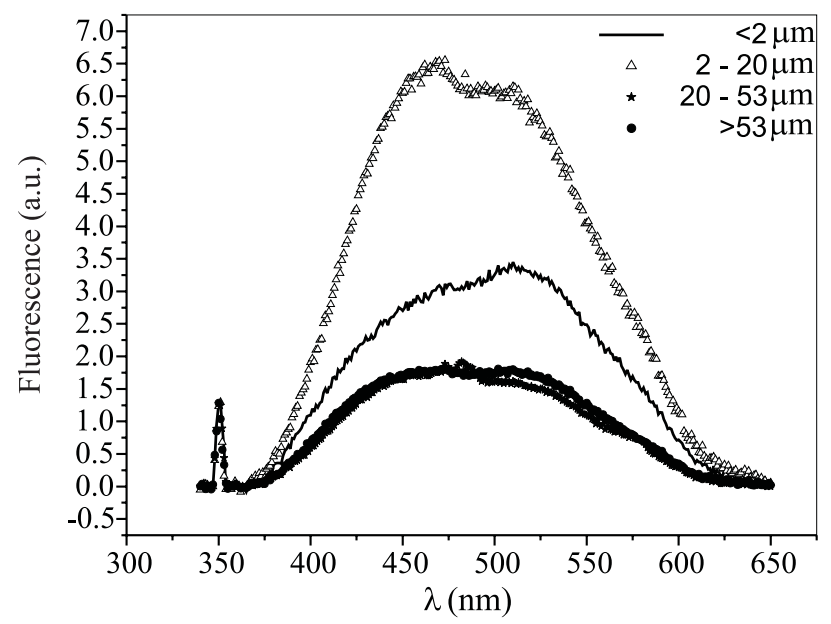

Figure 4 - Comparison among LIF emission spectra of different particle size fractions: $<2 \mu \mathrm{m}, 2-20 \mu \mathrm{m}, 20-53 \mu \mathrm{m}$ and $>53 \mu \mathrm{m}$ fractions.

these aromatics may represent a combination of the resistant portions of lignin plus aromatics from microbes associated with clay in small aggregates.

Martin-Neto et al. (1994) studied effects of cultivation on a Typic Argiudoll (province of Buenos Aires, Argentina) by Electron Paramagnetic Resonance and registered the highest semiquinone-type free radical contents for the 2-20 $\mu \mathrm{m}$ fraction. The higher levels of semiquinone-type free radical in samples $<50 \mu \mathrm{m}$ correlated with low $\mathrm{C} / \mathrm{N}$ ratios, which have been associated with a higher humification degree of OM.

Baldock et al. $(1992 ; 1997)$ found that sand fractions of A horizons from agricultural soils in Australia were dominated by O-alkyl C, using ${ }^{13} \mathrm{C}$ CPMAS NMR spectroscopy, and attributed this to polysaccharides in plant residues. On the other hand, clay fractions were dominated by alkyl $\mathrm{C}$, which is considered to relate to a gradual accumulation of plant derived waxes and microbial methylene type structures.

Studying chemical pathways of humification by ${ }^{13} \mathrm{C}$ CPMAS NMR spectroscopy, Zech et al. (1997) reported an increase of carboxyl C and Alkyl C, together with a slight increase of aromatic carbon, especially phenolic carbon, and a decrease of O-alkyl C during litter decomposition and humification. Schmidt et al. (2000) reported increasing alkyl-C-to-O-alkyl-C ratios and decreasing $\mathrm{C} / \mathrm{N}$ ratios for the $\mathrm{A}$ horizon of an agricultural Haplic Podzol with decreasing particle size (from $20-63 \mu \mathrm{m}$ to $<2 \mu \mathrm{m}$ ). These results support the hypothesis that decomposition of soil organic matter increases with decreasing particle size.

Zsolnay et al. (1999) propose a humification index based on the fact that the emission spectra tends to shift towards longer wavelengths as fluorescing molecules become more condensed (lower $\mathrm{H} / \mathrm{C}$ ratios). Since humification is considered to be associated with 
decreasing $\mathrm{H} / \mathrm{C}$ ratio, long emission wavelengths indicate a high humification degree of compounds.

The fraction $<2 \mu \mathrm{m}$ is shifted towards higher wavelengths, indicating the presence of more conjugated and more aromatic compounds, that can be either long polymethylenic chains or phenolic carbons resulting from lignin degration. The $2-20 \mu \mathrm{m}$ fraction presents two maxima. This can be attributed to a mixture of conjugated compounds more and less aromatic, as pointed out by Oades et al. (1987). The 20-53 $\mu \mathrm{m}$ fraction is shifted towards lower wavelengths, indicating the presence of less conjugated and less aromatic compounds. The last fraction, $>53 \mu \mathrm{m}$, shows two maxima at $455 \mathrm{~nm}$ and $510 \mathrm{~nm}$; once again there is a mixture of conjugated compounds, but their concentrations are low. Carbons bounded to minerals of the $>53 \mu \mathrm{m}$ fraction were as fluorescent as carbons of 20$53 \mu \mathrm{m}$ fraction in all treatments except N8. Since carbon contents were very different (0.27-0.54 for $>53 \mu \mathrm{m}$ fraction, and $0.82-1.40$ for $20-53 \mu \mathrm{m}$ fraction), compounds bounded to the $>53 \mu \mathrm{m}$ fraction had high quantic efficiency. Besides, the band of spectra centered at $455 \mathrm{~nm}$ for the $20-53 \mu \mathrm{m}$ fraction indicates that less aromatic compounds are incorporated in this fraction. In the $>53 \mu \mathrm{m}$ fraction spectra there was a band at $510 \mathrm{~nm}$. This means that the conservation of more conjugated compounds with high degree of oxygen or nitrogen substitution can occur. The changes in the shape of the spectra indicate that the lower the granulometric fraction, the higher the conjugation degree of aromatic compounds bounded to them.

The 2-20 $\mu \mathrm{m}$ fraction showed the highest fluorescence intensity, indicating higher aromaticity compared to other fractions. This is related to the high carbon content (about 5\%) of this fraction. The spectra of this fraction show its heterogeneity and a high concentration of compounds, with fluorescence centered at $510 \mathrm{~nm}$, compared to the $<2 \mu \mathrm{m}$ fraction. This is typical for linearly-condensed aromatic ring systems substituted by carbonyl and carboxyl groups and/or other unsaturated bond systems capable of high degree of resonance, indicating an increase of the conjugation of the electron $\pi$ system (Senesi et al., 1991).

Studies of humin fraction tightly associated with soil mineral fraction are relevant and represent the main advantage of particle size fractionation under chemical fractionation, which allows studying the distribution of $\mathrm{OM}$ within the mineral matrix of soil. The quality of SOM measured in whole soil chemical and physical fractions, was not influenced by the used sludge treatments. Since these results were similar to those obtained with more sophisticated spectroscopic technique, such as EPR, LIF spectroscopy techniques shows promise for OM studies in whole soils, including Oxisols.

\section{ACKNOWLEDGEMENTS}

To FAPESP (project: 99/09133-4), CEPOF (project: 98/14270-8), and PADCT/CNPq (project: 62 0324/98-8), Brazilian funding agencies, for financial support.

\section{REFERENCES}

BALDOCK, J.A.; OADES, J.M.; WATERS, A.G.; PENG, X.; VASSALLO, A.M.; WILSON M.A. Aspects of the chemical structure of soil organic materials as revealed by solid-state ${ }^{13} \mathrm{C}$ NMR spectroscopy. Biogeochemistry, v.16, p.1-42, 1992.

BALDOCK, J.A.; OADES, J.M.; NELSON, P.N.; SKENE, T.M.; GOLCHIN, A.; CLARKE, P. Assessing the extent of decomposition of natural organic materials using solid-state ${ }^{13} \mathrm{C}$ NMR spectroscopy. Australian Journal of Soil Research, v.35, p.1061-1083, 1997.

BAYER, C.; MIELNICZUK, J.; MARTIN-NETO, L. Efeito de sistemas de preparo e de cultura na dinâmica da matéria orgânica e na mitigação das emissões de $\mathrm{CO}_{2}$. Revista Brasileira de Ciência do Solo, v.24, p.599-607, 2000.

DAI, K.H.; JOHNSON, C.E. Applicability of solid-state ${ }^{13} \mathrm{C}$ CP/MAS NMR analysis in Spodosols: chemical removal of magnetic materials. Geoderma, v.93, p.289-310, 1999.

DERENNE, S.; POIRIER, N.; ROUZAUD, J.N.; MARIOTTI, A.; LARGEAU, C. Recent advances in the characterization of complex, refractory, organic macromolecules in soil. In: INTERNATIONAL MEETING OF THE INTERNATIONAL HUMIC SUBSTANCES SOCIETY, 10., Toulouse. 2000. Proceedings. Toulouse, 2000.

GONÇALVES, C.N.; DALMOLIN, R.S.D.; DICK, D.P.; KNICKER, H.; KLAMT, E.; KÖGEL-KNABNER, I. The effects of $10 \% \mathrm{HF}$ treatment on the resolution of CPMAS ${ }^{13} \mathrm{C}$ NMR spectra and on the quality of organic matter in Ferralsols. Geoderma, v.116, p.373-392, 2003.

KALBITZ, K.; GEYER, S.; GEYER, W. A comparative characterization of dissolved organic matter by means of original aqueous samples and isolated humic substances. Chemosphere, v.40, p.1305-1312, 2000.

MARTIN-NETO, L.; ANDRIULO, A.E.; TRAGHETTA, D. Effects of cultivation on ESR spectra of organic matter from soil size fractions of a mollisol. Soil Science, v.157, p.365-372, 1994.

MARTIN-NETO, L.; SAAB, S.C.; FERREIRA, J.A.; NASCIMENTO, O.R.; BAYER, C.; NOVOTNY, E.H.; MIELNICZUK, J. Recents applications of ESR spectroscopy in soil humic substances research. In: INTERNATIONAL MEETING OF THE INTERNATIONAL HUMIC SUBSTANCES SOCIETY, 10., Toulouse, 2000. Proceedings. Toulouse, 2000.

MCGARRY, S.F.; BAKER, A. Organic acid fluorescence: applications to speleothem palaeoenvironmental reconstruction. Quaternary Science Reviews, v.19, p.1087-1101, 2000.

MELO, W.J.; MARQUES, M.O. Potencial do lodo de esgoto como fonte de nutrientes para as plantas. In: BETTIOL, W.; CAMARGO, O.A. (Ed.) Impacto ambiental do uso agrícola do lodo de esgoto. Jaguariúna: EMBRAPA Meio Ambiente, 2000. chap.5, p.109-141.

MILORI, D.M.B.P.; MARTIN-NETO, L.; BAYER, C.; MIELNICZUK, J.; BAGNATO, V.S. Humification degree of soil humic acids determined by fluorescence spectroscopy. Soil Science, v.167, p.739749, 2002.

MILORI, D.M.B.P.; GALETI, H.V A.; MARTIN-NETO, L.; DIECKOW, J.; GONZÁLEZ-PÉREZ, M.; BAYER, C.; SALTON, J. Organic matter study of whole soil samples using laser-induced fluorescence spectroscopy. Soil Science Society of America Journal, v.70, p.5763, 2006.

NELSON, P.W.; SOMMERS, C.E. Total C, organic C and organic matter. In: SPARKS, D.L. (Ed.) Methods of soil analysis. Part 3. Madison: SSSA, 1996. p.539-579. 
OADES, J.M.; VASSALLO, A.M.; WATERS, A.G.; WILSON, M.A. Characterization of organic matter in particle size and density fractions from a Red-brown Earth by solid-state ${ }^{13}$ C N.M.R. Australian Journal of Soil Research, v.25, p.71-82, 1987.

PICCOLO, A.; ZACCHEO, P.; GENEVINI, P.G. Chemical characterization of humic substances extracted from organic-wasteamended soils. Bioresources and Technology, v.40, p.275-282, 1992.

SCHMIDT, M.W.I.; KNICKER, H.; HATCHER, P.G.; KÖGELKNABNER, I. Improvement of ${ }^{13} \mathrm{C}$ and ${ }^{15} \mathrm{~N}$ CPMAS NMR spectra of bulk soils, particle size fractions and organic material by treatment with $10 \%$ hydrofluoric acid. European Journal of Soil Science, v.48, p.319-328, 1997.

SCHMIDT, M.W.I.; KNICKER, H.; KÖGEL-KNABNER, I. Organic matter accumulating in Aeh e Bh horizons of a Podzol - chemical characterization in primary organo-mineral associations. Organic Geochemistry, v.31, p.727-734, 2000.

SENESI, N.; MIANO, T.M.; PROVENZANO, M.N.; BRUNETTI, G. Characterization, differentiation and classification of humic substances by fluorescence spectroscopy. Soil Science, v.152, p.259271,1991

SKJEMSTAD, J.O.; CLARKE, P.; TAYLOR, J.A.; OADES, J.M.; NEWMAN, R.H. The removal of magnetic materials from surface soils. A solid state ${ }^{13} \mathrm{C}$ CP/MAS N.M.R. study. Australian Journal of Soil Research, v.32, p.1215-1229, 1994.
STEVENSON, F.J. Humus chemistry: genesis, composition, reactions. New York: John Wiley, 1994.

TANNER, C.B.; JACKSON, M.L. Nomographs of sedimentation times for soil particles under gravity or centrifugal acceleration. Soil Science Society of America Proceedings, v.12, p.60-65, 1947.

VARADACHARI, C.; CHATTOPADHYAY, T.; GHOSH, K. Complexation of humic substances with oxides of iron and aluminum. Soil Science, v.162, p.28-34, 1997.

ZECH, W.; SENESI, N.; GUGGENBERGER, G.; KAISER, K.; LEHMANN, J.; MIANO, T.M.; MILTNER, A.; SCHROTH, G. Factors controlling humification and mineralization of soil organic matter in the tropics. Geoderma, v.79, p.117-161, 1997.

ZSOLNAY, A.; BAIGAR, E.; JIMENEZ, M.; STEINWEG, B.; SACCOMANDI, F. Differentiating with fluorescence spectroscopy the sources of dissolved organic matter in soils subjected to drying. Chemosphere, v.38, p.45-50, 1999.

Received June 08, 2005 Accepted May 16, 2006 